\title{
Anti-oxidative Effect of Ligustrazine on Treatment and Prevention of Atherosclerosis
}

\author{
Gui-dong Huang, Jian Mao* and Zhong-wei Ji \\ State Key Laboratory of Food Science and Technology, School of Food Science and Technology, Jiangnan University, Wuxi \\ 214122, PR China
}

*For correspondence: Email: maojiand417@163.com; Tel: +86-510-8532-9062; Fax: +86-510-8591-2155

Received: 11 July 2013

Revised accepted: 24 October 2013

\begin{abstract}
Purpose: To investigate the protective effects of ligustrazine on oxidative stress-induced atherosclerosis.

Methods: The indicators related to oxidative stress were determined using commercially available assay kits. MTT assay was used to assess the survival rate of human umbilical vein endothelial cells (HUVECs). HUVECs apoptosis was analyzed using fluorescence staining and flow cytometry. mRNA expression level and activity of caspases 3, 8, and 9 were determined via quantitative real-time polymerase chain reaction (PCR) and caspase 3, 8, and 9 assay kits.

Results: Ligustrazine concentration of $<80 \mu \mathrm{mol} / \mathrm{L}$ had negligible inhibitory effect on HUVECs viability and protected HUVECs against oxygen stress damage by regulating the indicators related to oxidative stress. Flow cytometry results show that ligustrazine ameliorated $\mathrm{H}_{2} \mathrm{O}_{2}$-induced apoptosis, while the proportion of cells that stepped into early apoptosis and late apoptosis or necrosis were 52.7 and $0.6 \%$, respectively, in the $\mathrm{H}_{2} \mathrm{O}_{2}$ group, and 38.2 and $1.3 \%$, respectively, in the ligustrazine group. In addition, ligustrazine attenuated the up-regulation of caspase 3, 8, and 9 mRNA expression levels and activity. Conclusion: Ligustrazine can protect HUVECs against $\mathrm{H}_{2} \mathrm{O}_{2}$-induced injuries by regulating the indicators related to oxidative stress and suppressing the overexpression of caspases 3, 8, and 9. The protective mechanism of ligustrazine on $\mathrm{H}_{2} \mathrm{O}_{2}$-induced injury in HUVECs may be a caspase-dependent anti-apoptotic mechanism which provide important information for treating and preventing oxidative stress-induced atherosclerosis.
\end{abstract}

Keywords: Ligustrazine, Oxidative stress, Umbilical vein, Endothelial cells, Atherosclerosis

Tropical Journal of Pharmaceutical Research is indexed by Science Citation Index (SciSearch), Scopus, International Pharmaceutical Abstract, Chemical Abstracts, Embase, Index Copernicus, EBSCO, African Index Medicus, JournalSeek, Journal Citation Reports/Science Edition, Directory of Open Access Journals (DOAJ), African Journal Online, Bioline International, Open-J-Gate and Pharmacy Abstracts

\section{INTRODUCTION}

Atherosclerosis (AS) is the primary cause of cardiovascular and cerebrovascular diseases [1]. Substantial evidence indicates that oxidative stress contributes to the progression of AS [2]. Oxidative stress can result in endothelial damage [3]. Injury to endothelial cells is the initiating factor of AS [4].
Cells usually have three model systems for oxidative stress: extracellular sources of superoxide anion $\left(\mathrm{O}^{2-}\right)$, hydroxyl radical $\left(\mathrm{H}_{2} \mathrm{O}_{2}\right)$, and normobaric hyperoxia (elevated ambient oxygen) [5]. Among the three, $\mathrm{H}_{2} \mathrm{O}_{2}$ has been extensively used to induce endothelial cell-injury models in vitro because it can easily penetrate the plasma membrane and does not play a role in initiating lipid pre-oxidation and oxidizing DNA and amino acids [4]. 
Recently, many studies have suggested that natural bioactive compounds from plants can protect endothelial cells against oxidative damage [6]. Ligustrazine (tetramethy-pyrazine) is the major active ingredient extracted from Ligusticum chuanxiong and is widely applied in the treatment of vascular diseases in China [7]. Previous studies have reported that ligustrazine can effectively scavenge cytotoxic oxygen free radicals that can alleviate hepatic and kidney cell damage $[8,9]$. However, the potential mechanism of ligustrazine involved in AS was still obscure. Therefore, in the present study, the $\mathrm{H}_{2} \mathrm{O}_{2}$ induced oxidative stress model was established using human umbilical vein endothelial cells (HUVECs) to explore the anti-oxidative effects of ligustrazine on oxidative damaged endothelial cells and the underlying mechanism involved in the pathogenesis of AS.

\section{EXPERIMENTAL}

\section{Materials}

The HUVECs were provided by Nanchang University Medical School. The current study was approved by the Ethics Committee of Nanchang University (China). Trypsin and 3-(4, 5-dimethylthiazal-z-yl)-2, 5-diphenylterazolium (MTT) were purchased from Sigma (St. Louis, USA), and Dulbecco's Modified Eagle medium (DMEM) and fetal bovine serum (FBS) were purchased from GIBCO (Carlsbad, USA). Ligustrazine was obtained from the National Institute for the Control of Pharmaceutical and Biological Products (Beijing, China). The LDH, MDA, GSH, NOS, nitric oxide (NO), and SOD assay kits were from Nanjing Jiancheng Bioengineering Institute (Nanjing, China).

\section{Cell culture}

The HUVECs were cultured in $25 \mathrm{~cm}^{2}$ plastic flasks at $37{ }^{\circ} \mathrm{C}$ in a humidified $\mathrm{CO}_{2}$ incubator (95 $\%$ air and $5 \% \mathrm{CO}_{2}$ ). The complete medium for cell maintenance was $4.5 \mathrm{~g} / \mathrm{L}$ glucose DMEM containing 10\% FBS, L-glutamine, $100 \mathrm{lU} / \mathrm{mL}$ penicillin, and $100 \mathrm{lU} / \mathrm{mL}$ streptomycin. When cells were $80 \%$ confluent, they were subcultured using $0.25 \%$ trypsin and $0.02 \%$ EDTA, and the medium was changed every two days. Cells between passages 3 and 10 were used in the present study.

Determination of $\mathrm{H}_{2} \mathrm{O}_{2}$ concentration in oxidative stress model (MTT assay)

The concentration-dependent studies of HUVECs induced by $\mathrm{H}_{2} \mathrm{O}_{2}$ were conducted using MTT assay. HUVECs were counted and seeded into 96-well culture plates at a density of $5 \times 10^{3}$ cells/well. The cells were washed twice with PBS after incubation with various $\mathrm{H}_{2} \mathrm{O}_{2}$ concentrations $(0,50,100,200$, and $400 \mu \mathrm{M})$ for $8 \mathrm{~h}$. For each well, the cells were then incubated with $100 \mu \mathrm{L}$ MTT (final concentration of $0.5 \mathrm{mg} / \mathrm{mL}$ ) for $4 \mathrm{~h}$. After MTT removal, the colored formazan was dissolved in $100 \mu \mathrm{L}$ of DMSO. The absorption values were measured at $490 \mathrm{~nm}$ using a Thermo Scientific Multiskan MK3 Microplate Reader (Thermo Fisher, USA). The viability of HUVECs in each well was presented as percentage of control cells. Six independent replicates were performed for each group.

\section{Confocal laser scanning microscopy (CLSM)}

The HUVECs were cultured as described above and were stained with Hoechst 33258 for 30 min at $37^{\circ} \mathrm{C}$. Cell shape and nuclear morphology with apoptotic characteristics were observed immediately using Zeiss LSM 710 confocal laser scanning microscope (Carl Zeiss Microlmaging $\mathrm{GmbH}$, Germany).

\section{Evaluation of ligustrazine cytotoxicity}

The effect of ligustrazine on HUVEC viability was evaluated via MTT assay in 96-well plates at a cell density of $5 \times 10^{3}$ cells per well. The cells were washed twice with PBS, after being pretreated with ligustrazine $(10,20,40,80,160$, and $320 \mu \mathrm{mol} / \mathrm{L})$ for $24 \mathrm{~h}$. The MTT assay was done under the conditions described earlier.

\section{Evaluation of effect of ligustrazine on the viability of $\mathrm{H}_{2} \mathrm{O}_{2}$-induced HUVECs}

The cells were cultured as described above. The HUVECs were randomly divided into the control, $\mathrm{H}_{2} \mathrm{O}_{2}$, and five ligustrazine groups $(5,10,20,40$, and $80 \mu \mathrm{mol} / \mathrm{L}+100 \mu \mathrm{mol} / \mathrm{L} \quad \mathrm{H}_{2} \mathrm{O}_{2}$ ). Subconfluent cells were pre-treated with the medium containing various concentrations $(5,10,20,40$, and $80 \mu \mathrm{mol} / \mathrm{L})$ of ligustrazine for $24 \mathrm{~h}$. Thereafter, a final $100 \mu \mathrm{mol} / \mathrm{L} \quad \mathrm{H}_{2} \mathrm{O}_{2}$ concentration was added to the culture medium for $8 \mathrm{~h}$, which was designated as the ligustrazine group. The control group was treated with the culture medium only, whereas the oxidative injury model of HUVECs established using $\mathrm{H}_{2} \mathrm{O}_{2}$ was regarded as the $\mathrm{H}_{2} \mathrm{O}_{2}$ group. Subsequently, the effect of ligustrazine on the $\mathrm{H}_{2} \mathrm{O}_{2}$-induced HUVECs was measured via MTT assay.

\section{Evaluation of oxidative stress parameters}

The percentage of $\mathrm{LDH}$ release, NO production, SOD, GSH-Px, and NOS activities, and MDA concentration were determined using 
commercially available assay kits (Jiancheng Bioengineering Research Institute, Nanjing, China). All procedures complied with the manufacturer's instructions. In addition, the percentage of $\mathrm{LDH}$ release was defined as the release of $\mathrm{LDH}$ in the supernatant/(release of $\mathrm{LDH}$ in the supernatant + release of LDH from the cell lysate) $\times 100$.

\section{Flow cytometry}

Here, HUVECs were harvested, washed, and double-stained with an Annexin V-fluorescein isothiocyanate apoptosis detection kit (BD Biosciences, USA). The cells were incubated in the dark at $4{ }^{\circ} \mathrm{C}$ for $10 \mathrm{~min}$ to $15 \mathrm{~min}$ and analyzed using a BD FACS Calibur $^{\text {TM }}$ flow cytometry system (Becton Dickinson, USA). All tests were done in triplicate.

\section{Determination of the mitochondrial membrane potential $\left(\Delta \Psi_{\mathrm{m}}\right)$}

Rhodamine 123, a cationic fluorescent dye whose mitochondrial fluorescence intensity decreases quantitatively with the dissipation of the mitochondrial membrane potential, was used to evaluate perturbations in mitochondrial membrane potential [10]. The HUVECs were cultured as described above and divided into different groups (control, $\mathrm{H}_{2} \mathrm{O}_{2}$, and ligustrazine groups). After $24 \mathrm{~h}$ treatment, cells were harvested and washed twice with cold PBS and then incubated in the dark with rhodamine 123 $(1 \mu \mathrm{mol} / \mathrm{L})$ for $30 \mathrm{~min}$ at $37^{\circ} \mathrm{C}$. Fluorescence was measured using flow cytometry with an excitation wavelength of $485 \mathrm{~nm}$.

\section{Detection of caspase activity}

The cells were cultured and treated as aforementioned. The fluorometric specific detection kits (KeyGEN, China) containing fluorescent substrates were used to analyze the activities of caspase 3, 8 , and 9 . The protocol for detecting caspase activity was conducted according to the manufacturer's directions. Experiments were performed in triplicate.

\section{Quantitative real-time (qRT)-PCR analysis of mRNA expression}

The total RNA was extracted from cultured cells using Trizol reagent (Invitrogen, USA). The RNA concentrations were determined at $260 \mathrm{~nm}$, and the samples were then stored in a freezer. Firststrand cDNA was synthesized from $1 \mu \mathrm{g}$ of total RNA using PrimerScript ${ }^{\text {TM }}$ RT-PCR kit (TaKaRa Code: DRR041A) according to the manufacturer's instructions. The expression levels of genes ( $\beta$-actin, caspase- 3 , caspase-8, and caspase-9) in each sample were determined via qRT-PCR in the ABI 7900HT Real-Time PCR system (Applied Biosystems, USA). The florescence signals were detected with the $A B I$ 7900HT Version 2.3 sequence detection system (Applied Biosystems, USA). The PCR conditions were as follows: $95^{\circ} \mathrm{C}$ for $30 \mathrm{~s}$, followed by 40 cycles at $95^{\circ} \mathrm{C}$ for $5 \mathrm{~s}$, and $60{ }^{\circ} \mathrm{C}$ for $1 \mathrm{~min}$. The gene expression data were normalized to the endogenous control $\beta$-actin, and the relative mRNA expression was calculated using the comparative cycle threshold $(\Delta \mathrm{Ct})$ method. $\Delta \mathrm{Ct}$ is the difference between the $\mathrm{Ct}$ values of the target gene and $\beta$-actin. The primers used for qRT-PCR are listed in Table 1.

\section{Statistical analysis}

Statistical analysis was performed using the SPSS 17.0 package. The values are presented as mean \pm standard deviation (SD, $n \geq 3$ ). Oneway ANOVA and Student's t-test were conducted to determine statistical significance. Differences between groups were considered significant at $p<0.05$.

\section{RESULTS}

\section{Concentration-dependent survival rate of $\mathrm{H}_{2} \mathrm{O}_{2}$-induced HUVECs}

Studies on the concentration-dependent survival rate of $\mathrm{H}_{2} \mathrm{O}_{2}$-induced $\mathrm{HUVECs}$ were performed in the present study. As shown in Figure 1, the survival rates gradually decreased with the increase in $\mathrm{H}_{2} \mathrm{O}_{2}$ concentration. When $\mathrm{H}_{2} \mathrm{O}_{2}$

Table 1: Primer sequences used for qRT-PCR

\begin{tabular}{llll}
\hline Gene & $\begin{array}{l}\text { Forward primers } \\
\text { (5'to 3') }\end{array}$ & $\begin{array}{l}\text { Reverse primers } \\
\text { (5'to 3') }\end{array}$ & $\begin{array}{l}\text { Product } \\
\text { size (bp) }\end{array}$ \\
\hline 3-actin & AGTTGCGTTACACCCTTTCTTG & CACCTTCACCGTTCCAGTTTT & 152 \\
Caspase-3 & TGTGAGGCGGTTGTGGAAGAGT & AATGGGGGAAGAGGCAGGTGCA & 182 \\
Caspase-8 & TGTCCTTCCTGAGGGAGCTGCT & TGAGCCCTGCCTGGTGTCTGAA & 115 \\
Caspase-9 & TGGAGGATTTGGTGATGTCGAGCA & ATCTGGCTCGGGGTTACTGCCA & 97 \\
\hline
\end{tabular}


concentration was higher than $100 \mu \mathrm{mol} / \mathrm{L}$, the survival rate decreased by $11.45 \pm 2.62 \%$ ( $p<$ 0.05 , compared with control), suggesting that $100 \mu \mathrm{mol} / \mathrm{L}$ of $\mathrm{H}_{2} \mathrm{O}_{2}$ can induce cell injury. Previous studies indicate $\mathrm{H}_{2} \mathrm{O}_{2}$ concentrations in the oxidative stress model system ranging from $10^{-5} \mathrm{~mol} / \mathrm{L}$ to $10^{-3} \mathrm{~mol} / \mathrm{L}$, which coincide with our results [11].

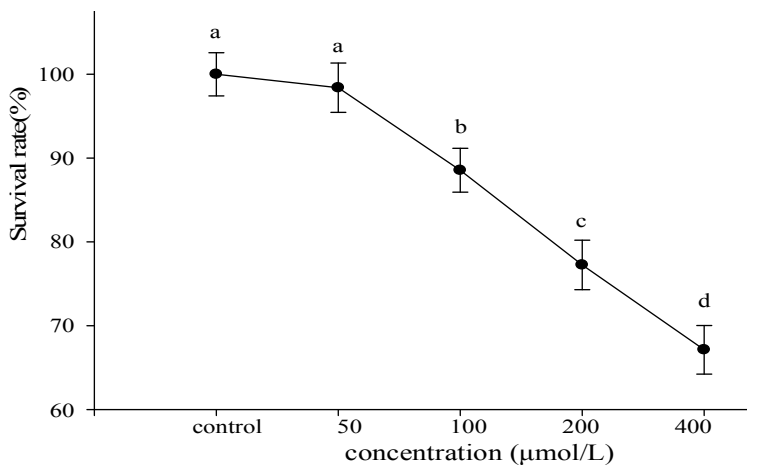

Figure 1: Survival rates of HUVECs induced by $\mathrm{H}_{2} \mathrm{O}_{2}$. Values are mean \pm S.D. $(n \geq 4)$. Values with different letters are significantly difference in a concentrationdependent manner $(p<0.05)$.

\section{Apoptosis of HUVECs detected via Hoechst 33258 fluorescence staining}

The CLSM results indicate that normal cells display weak fluorescence, whereas apoptotic cells show increasing bright fluorescence and typical apoptotic bodies. As shown in Figure 2, the chromatin in nucleus seemed to be condensed and marginalized in the $\mathrm{H}_{2} \mathrm{O}_{2}$ group, suggesting that $\mathrm{H}_{2} \mathrm{O}_{2}$ can result in HUVECs apoptosis.

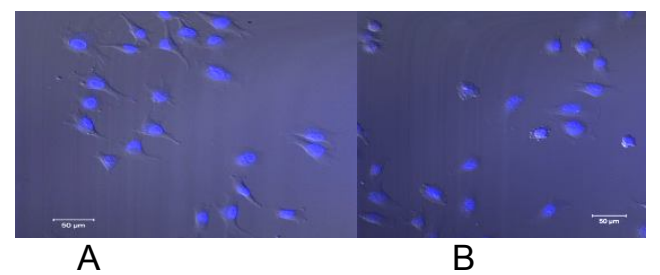

Figure 2: The micrograph of HUVECs in the control group (A) and $\mathrm{H}_{2} \mathrm{O}_{2}$ group (B) by CLSM. The results show that $\mathrm{H}_{2} \mathrm{O}_{2}$ can result in HUVECs apoptosis.

\section{Cytotoxicity of ligustrazine on HUVECs}

The effect of ligustrazine on the viability of normal HUVECs was concentration dependent (Figure 3). When the concentration was more than $160 \mu \mathrm{mol} / \mathrm{L}$, the survival rate was 81.29 $\pm 3.18 \%$, which is significantly less than that of the control group $(p<0.05)$. However, ligustrazine at concentrations $\leq 80 \mu \mathrm{mol} / \mathrm{L}$ had negligible inhibitory effect on HUVECs survival. Therefore, ligustrazine concentrations less than
$80 \mu \mathrm{mol} / \mathrm{L}$ were used for the subsequent experiments.

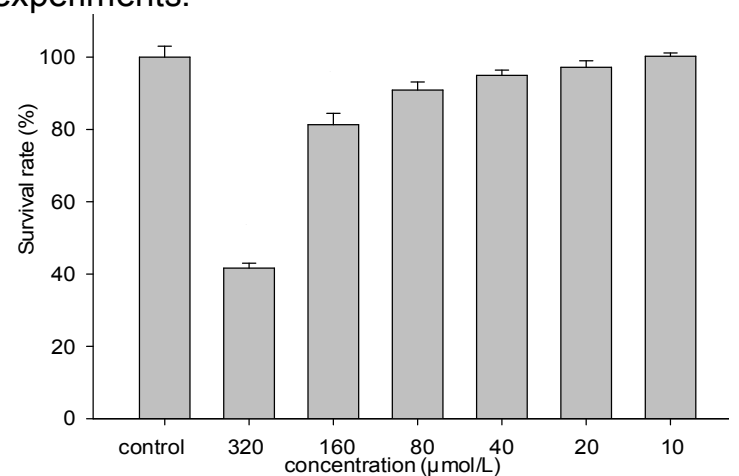

Figure 3: The effect of ligustrazine on the survival rates of HUVECs.

\section{Protective effect of ligustrazine on the viability of $\mathrm{H}_{2} \mathrm{O}_{2}$-induced HUVECs}

The protective effects of ligustrazine on the viability of $\mathrm{H}_{2} \mathrm{O}_{2}$-induced HUVECs were evaluated via MTT assay. As shown in Figure 4, the survival rate of HUVECs was about $64 \% \pm 3.8 \%$ after exposure to $100 \mu \mathrm{mol} / \mathrm{L}$ of $\mathrm{H}_{2} \mathrm{O}_{2}$ for $8 \mathrm{~h}$. However, pre-incubation of HUVECs with ligustrazine $(5,10,20,40$, and $80 \mu \mathrm{mol} / \mathrm{L})$ for $24 \mathrm{~h}$ can increase the viability of $\mathrm{H}_{2} \mathrm{O}_{2}$-induced HUVECs in a dose-dependent manner ( $p<$ $0.05)$, and the survival rates were $67.06 \pm 3.95$, $71.75 \pm 1.24,74.44 \pm 3.80,82.00 \pm 1.20$, and $86.91 \pm 2.86 \%$, respectively. These rates suggest that ligustrazine can protect HUVECs against $\mathrm{H}_{2} \mathrm{O}_{2}$-induced injury.

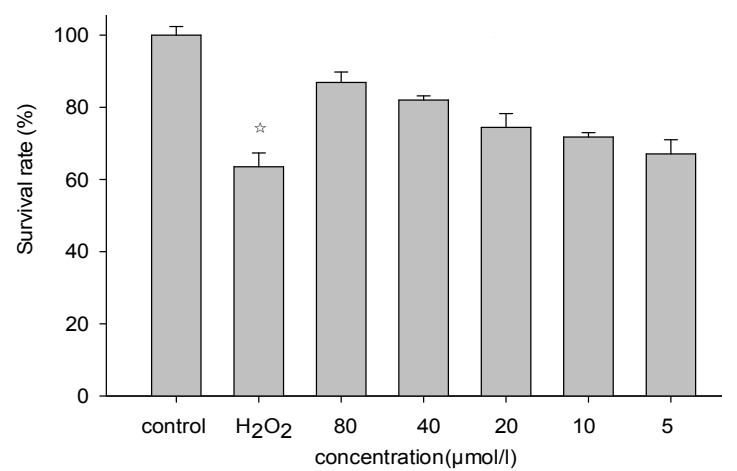

Figure 4: The protective effects of ligustrazine on HUVECs against oxidative injury.

Pentagram ( $\lesssim$ ) indicates statistically significant differences between the $\mathrm{H}_{2} \mathrm{O}_{2}$ group and control group.

\section{Influence of ligustrazine on oxidative stress indicators of $\mathrm{H}_{2} \mathrm{O}_{2}$-induced injury}

LDH release, MDA and NO concentrations, and SOD, GSH-Px, and NOS activities were investigated to further confirm the protective effects of ligustrazine on $\mathrm{H}_{2} \mathrm{O}_{2}$-induced injury in HUVECs. As shown in Table 2, LDH release was 
$16.28 \pm 1.71 \%$ in the control group, and a dramatic increase $(34.89 \pm 0.98 \%)$ was observed after exposure to $100 \mu \mathrm{mol} / \mathrm{L}$ of $\mathrm{H}_{2} \mathrm{O}_{2}$ for $8 \mathrm{~h}$. However, pre-treatment with the different concentrations of ligustrazine ( $>5 \mu \mathrm{mol} / \mathrm{L}$ ) for $24 \mathrm{~h}$ attenuated the $\mathrm{H}_{2} \mathrm{O}_{2}$-induced increase in LDH release $(p<0.05$, Table 2$)$.

The MDA concentration in the control group was $23.78 \pm 2.15 \mathrm{nmol} / \mathrm{mg}$ of protein, whereas that in HUVECs treated with $100 \mu \mathrm{mol} / \mathrm{L}$ of $\mathrm{H}_{2} \mathrm{O}_{2}$ for $8 \mathrm{~h}$ significantly increased $(45.70 \pm 3.14 \mathrm{nmol} / \mathrm{mg}$ of protein) $(p<0.05$, Table 2$)$. Meanwhile, the MDA concentrations in cells pre-treated with various concentrations of ligustrazine $(5,10,20,40$, and $80 \mu \mathrm{mol} / \mathrm{L})$ for $24 \mathrm{~h}$ decreased.

As shown in Table 2, the NO level and NOS activity in HUVECs exposed to $100 \mu \mathrm{mol} / \mathrm{L}$ of $\mathrm{H}_{2} \mathrm{O}_{2}$ for $8 \mathrm{~h}(p<0.05$, with $27.44 \pm 4.34 \mu \mathrm{mol} / \mathrm{L}$ and $1.95 \pm 0.20 \mathrm{U} / \mathrm{mg}$ of protein, respectively) significantly decreased compared with those of the control group $(73.30 \pm 7.00 \mu \mathrm{mol} / \mathrm{L}$ and 4.18 $\pm 0.77 \mathrm{U} / \mathrm{mg}$ of protein, respectively). However, $24 \mathrm{~h}$ pre-treatment with ligustrazine $(5,10,20$, 40 , and $80 \mu \mathrm{mol} / \mathrm{L})$ could trigger a distinct, dosedependent increase in these indicators.
Treating HUVECs with $100 \mu \mathrm{mol} / \mathrm{L}$ of $\mathrm{H}_{2} \mathrm{O}_{2}$ caused a significant decrease in SOD and GSH$\mathrm{Px}$ activities (45.16 \pm 3.25 and $77.81 \pm$ $4.29 \mathrm{U} / \mathrm{mg}$ of protein, respectively) compared with that in the control group (129.76 \pm 15.52 and $160.13 \pm 3.73 \mathrm{U} / \mathrm{mg}$ of protein, respectively) $(p<0.05$, Table 2). However, pre-incubation with ligustrazine $(5,10,20,40$, and $80 \mu \mathrm{mol} / \mathrm{L})$ for $24 \mathrm{~h}$ attenuated the changes in SOD and GSHPx activities.

All of these results suggest that ligustrazine can be an anti-oxidative agent protecting HUVECs against oxidative stress.

\section{Effect of ligustrazine on apoptosis}

The percentages of cells that stepped into early apoptosis and late apoptosis or necrosis were $52.7 \%$ and $0.6 \%$, respectively, in the $\mathrm{H}_{2} \mathrm{O}_{2}$ group, and $38.2 \%$ and $1.3 \%$, respectively, in the ligustrazine group ( $80 \mu \mathrm{mol} / \mathrm{L})$ (Figure 5). These results suggest that ligustrazine has a protective effect on HUVECs against oxidative damage, which is particularly important in maintaining normal physiological function and preventing the formation of atherosclerotic plaques.

Table 2: Effect of ligustrazine on oxidative stress in HUVECs

\begin{tabular}{|c|c|c|c|c|c|c|}
\hline Group & $\begin{array}{l}\text { LDH release } \\
(\%)\end{array}$ & $\begin{array}{l}\text { MDA } \\
\text { (nmol/mgprot) }\end{array}$ & $\begin{array}{l}\text { NOS } \\
\text { (U/mgprot) }\end{array}$ & $\begin{array}{l}\text { NO } \\
(\mu \mathrm{mol} / \mathrm{L})\end{array}$ & $\begin{array}{l}\text { SOD } \\
\text { (U/mgprot) }\end{array}$ & $\begin{array}{l}\text { GSH-Px } \\
\text { (U/mgprot) }\end{array}$ \\
\hline Control & $16.28 \pm 1.71$ & $23.78 \pm 2.15$ & $4.18 \pm 0.77$ & $73.30 \pm 7.00$ & $129.76 \pm 15.52$ & $160.13 \pm 3.73$ \\
\hline $\mathrm{H}_{2} \mathrm{O}_{2}$ & $34.89 \pm 0.89^{* a}$ & $45.70 \pm 3.14^{\star a}$ & $1.95 \pm 0.20^{\star a}$ & $27.44 \pm 4.34^{\star a}$ & $45.16 \pm 3.25^{\star a}$ & $77.81 \pm 4.29^{* a}$ \\
\hline $\begin{array}{l}5 \mu \mathrm{M} \text { of } \\
\text { Liqustrazine }\end{array}$ & $33.68 \pm 0.81^{a}$ & $42.98 \pm 2.96^{\mathrm{ab}}$ & $2.15 \pm 0.50^{\mathrm{a}}$ & $32.20 \pm 4.13^{\mathrm{ab}}$ & $57.98 \pm 9.53^{a}$ & $81.75 \pm 1.08^{\mathrm{ab}}$ \\
\hline $\begin{array}{l}10 \mu \mathrm{M} \text { of } \\
\text { Ligustrazine }\end{array}$ & $32.78 \pm 1.49^{b}$ & $40.23 \pm 2.10^{\mathrm{abc}}$ & $2.23 \pm 0.29^{\mathrm{ab}}$ & $46.05 \pm 8.47^{\mathrm{ab}}$ & $60.64 \pm 8.85^{\mathrm{b}}$ & $83.37 \pm 2.15^{b c}$ \\
\hline $\begin{array}{l}210 \mu \mathrm{M} \text { of } \\
\text { Ligustrazine }\end{array}$ & $29.86 \pm 0.44^{c}$ & $38.66 \pm 4.91^{\mathrm{bcd}}$ & $2.60 \pm 0.35^{\mathrm{bc}}$ & $53.60 \pm 8.02^{a b}$ & $74.00 \pm 3.63^{b}$ & $90.44 \pm 4.06^{\mathrm{cd}}$ \\
\hline $\begin{array}{l}40 \mu \mathrm{M} \text { of } \\
\text { Ligustrazine }\end{array}$ & $27.42 \pm 0.83^{d}$ & $36.52 \pm 2.68^{\mathrm{cd}}$ & $2.94 \pm 0.81^{\mathrm{cd}}$ & $68.07 \pm 3.30^{b}$ & $82.51 \pm 1.68^{C}$ & $96.96 \pm 2.43^{d}$ \\
\hline $\begin{array}{l}80 \mu \mathrm{M} \text { of } \\
\text { Ligustrazine }\end{array}$ & $25.90 \pm 0.50^{d}$ & $34.41 \pm 3.65^{\mathrm{d}}$ & $3.01 \pm 0.33^{d}$ & $69.61 \pm 11.42^{b}$ & $107.28 \pm 5.18^{c}$ & $110.39 \pm 9.56^{\mathrm{e}}$ \\
\hline
\end{tabular}

Note: Asterik (*) indicates statistically significant differences between the control and $\mathrm{H}_{2} \mathrm{O}_{2}$ group. a, b, c, d, e indicate statistically significant differences between the $\mathrm{H}_{2} \mathrm{O}_{2}$ group and ligustrazine group.

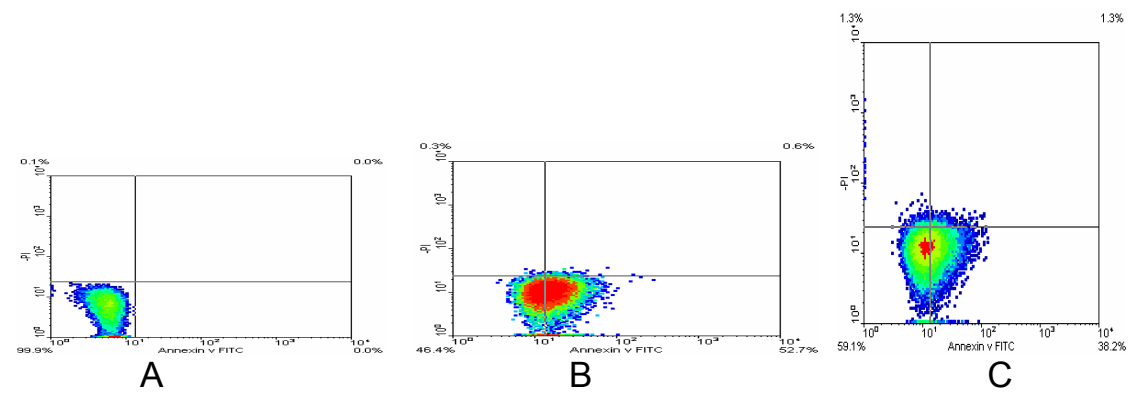

Figure 5: The flow cytometry of HUVECs apoptotic cells after treatment with the $\mathrm{H}_{2} \mathrm{O}_{2}$ and ligustrazine. Quadrant analysis of fluorescence intensity of gated cells in Annexin V-FITC and PI channels was from 16,000 events. A= control; $\mathrm{B}=\mathrm{H}_{2} \mathrm{O}_{2}$ group; $\mathrm{C}=$ ligustrazine group $(80 \mu \mathrm{mol} / \mathrm{L})$. 
Effect of ligustrazine on $t$ mitochondrial membrane potential $\left(\Delta \Psi_{m}\right)$

The changes in mitochondrial membrane potential reflect the initial cell apoptotic phenomenon. Here, $\Delta \Psi_{\mathrm{m}}$ was measured using flow cytometry. A substantial decrease in $\Delta \Psi_{m}$ was observed in HUVECs upon exposure to
$\mathrm{H}_{2} \mathrm{O}_{2}$. However, after pre-treatment with different concentrations of ligustrazine $(20$ and $80 \mu \mathrm{mol} / \mathrm{L}), \Delta \Psi_{\mathrm{m}}$ increased to a value higher than that in the $\mathrm{H}_{2} \mathrm{O}_{2}$ group (Figure 6). These data indicate that ligustrazine could protect HUVECs against oxidative stress via mitochondrial induction pathways.
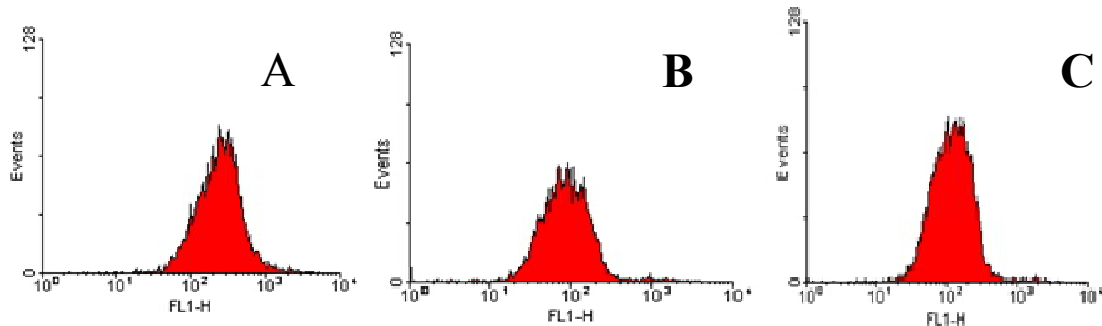

$\mathrm{C}$

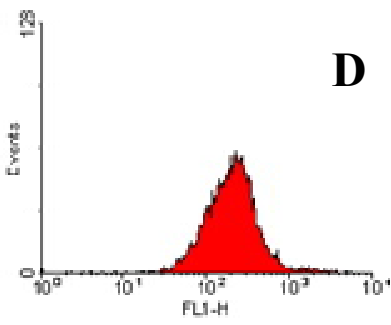

Figure 6: Effect of ligustrazine on mitochondrial membrane potential in HUVECs.

The $\Delta \psi_{m}$ depolarization was detected using flow cytometry with Rh123 staining. $A=$ control group; $B=\mathrm{H}_{2} \mathrm{O}_{2}$ group; $C=$ low ligustrazine concentration $(20 \mu \mathrm{mol} / \mathrm{L}) ; \mathrm{D}=$ high ligustrazine concentration $(80 \mu \mathrm{mol} / \mathrm{L})$.

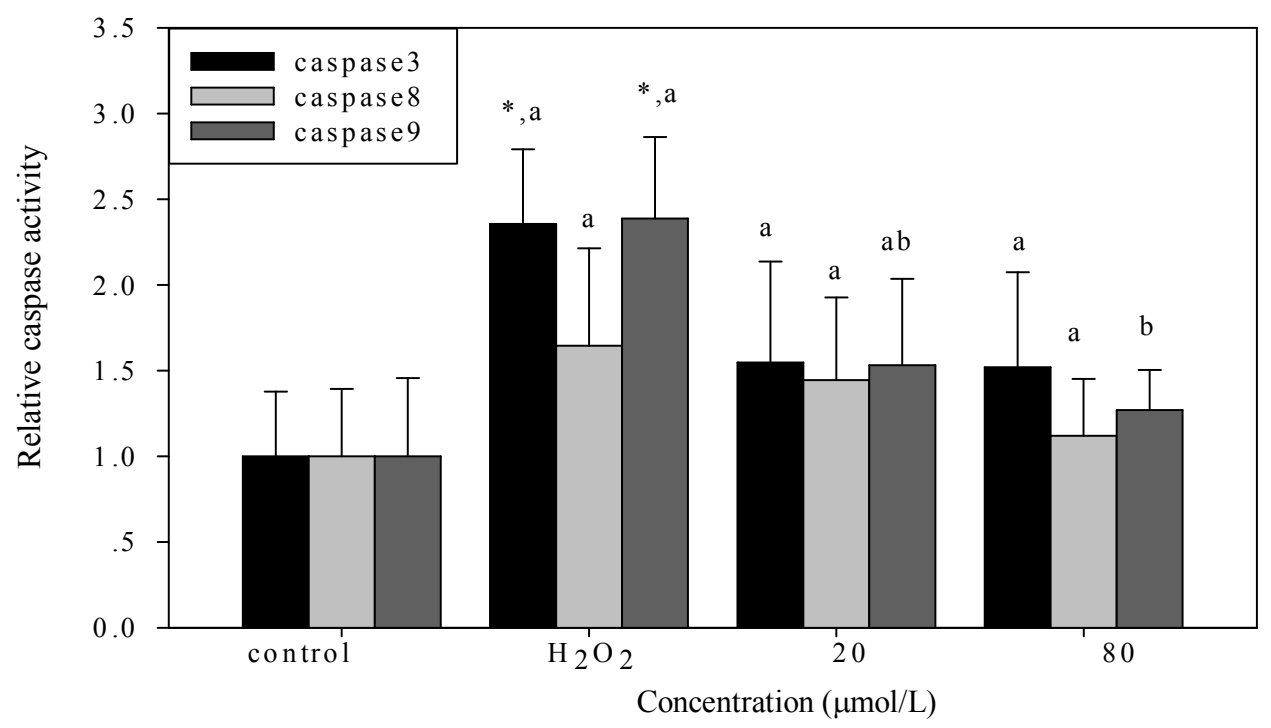

Figure 7: Effect of ligustrazine on the activities of caspase 3, 8 and 9 in HUVECs.

Asterisks $\left(^{*}\right)$ indicate statistically significant differences between the control, $\mathrm{H}_{2} \mathrm{O}_{2}$ group, and ligustrazine group $(p<0.05)$. Values with different letters indicate statistically significant differences between the $\mathrm{H}_{2} \mathrm{O}_{2}$ group and ligustrazine group $(p<0.05)$.

\section{Effect of ligustrazine on caspase 3, 8, and 9 activities}

Caspase 3, 8, and 9 activities are associated with specific intracellular polypeptide degradation during apoptosis. Caspase 8 and 9 are initiator caspases, and caspase 3 is considered as the main executor of apoptosis. The results in Figure 7 indicate that caspase 3,8 , and 9 activities are lower in the ligustrazine group than those in the $\mathrm{H}_{2} \mathrm{O}_{2}$ group, suggesting that ligustrazine can protect HUVECs against oxidative stress and, hence, apoptosis.

\section{Effect of ligustrazine on mRNA expression of caspase 3,8 , and 9}

The mRNA expression levels of caspase 3,8 , and 9 were measured via qRT-PCR. The results reveal that the mRNA levels of caspase 3,8 , and 9 are significantly up-regulated in the $\mathrm{H}_{2} \mathrm{O}_{2}$ group compared with those in the control group $(p<$ 0.05 ). Pre-treatment with ligustrazine in endothelial cells led to a decrease in the mRNA expression levels of caspase 3,8 , and 9 that coincide with the enzyme changes (Figure 8), suggesting that the anti-apoptotic mechanism of ligustrazine may be caspase dependent. 


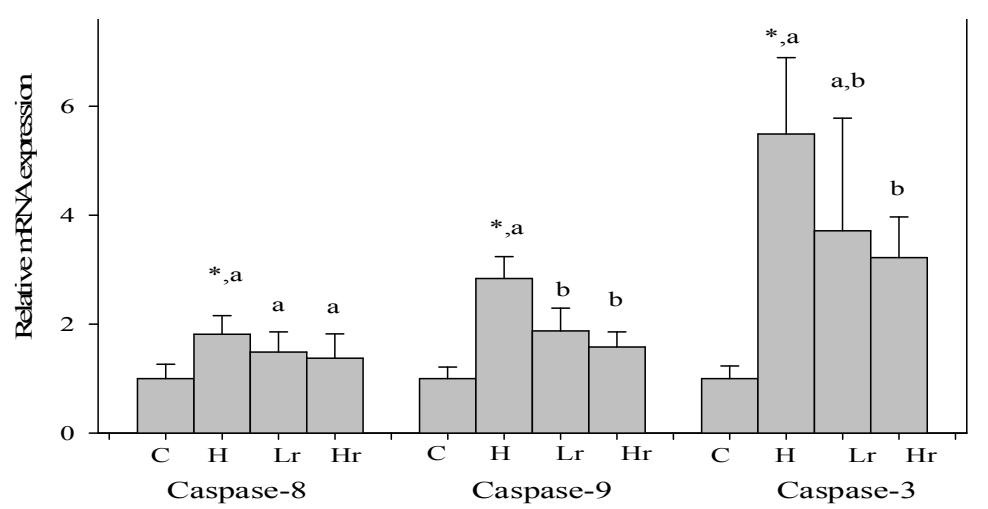

Figure 8: Effect of ligustrazine on the mRNA expression of caspase 3, 8, 9 in HUVECs. $\mathrm{C}=$ control group; $\mathrm{H}=$ $\mathrm{H}_{2} \mathrm{O}_{2}$ group; $\mathrm{Lr}=$ Low ligustrazine concentration $(20 \mu \mathrm{mol} / \mathrm{L}) ; \mathrm{Hr}=$ High ligustrazine concentration $(80 \mu \mathrm{mol} / \mathrm{L})$. Asterisk $\left(^{*}\right)$ indicates statistically significant differences between control, $\mathrm{H}_{2} \mathrm{O}_{2}$ group, and ligustrazine group $(p<$ 0.05). Values with different letters indicate statistically significant differences between $\mathrm{H}_{2} \mathrm{O}_{2}$ and ligustrazine groups $(p<0.05)$.

\section{DISCUSSION}

A variety of factors, such as inflammatory cytokines, reactive oxygen species (ROS), and lipid oxidation enzymes, could result in vascular endothelial cell damage, of which the damage caused by ROS is the most crucial [12]. Oxygen free radicals, the main oxidizing substances, participate in the body's normal physiological activity. Oxyradicals are closely related to the body's metabolism and signal transduction and play an important role in cell physiological function. Normally, a small amount of oxyradicals are by-products of cellular metabolism. However, under certain conditions, large amounts of oxyradicals are generated from the intracellular system, which may cause irreversible oxidative damages. $\mathrm{H}_{2} \mathrm{O}_{2}$ has been suggested as inducer of apoptosis in several types of cells [13]. In the current study, the oxidative injury model was established with $\mathrm{H}_{2} \mathrm{O}_{2}$ as inducer of HUVEC apoptosis. As reported previously, the viability and proliferation of HUVECs significantly decreased after $\mathrm{H}_{2} \mathrm{O}_{2}$ exposure. Morphological analysis showed similar results, with the chromatin in nucleus appearing to be condensed and marginalized in the $\mathrm{H}_{2} \mathrm{O}_{2}$ group upon observation via CLSM.

ROS affects lipids and leads to lipid peroxidation, which thus produces MDA. MDA might combine with proteins, amino acids, and other cellular components and hence change the structure of phospholipids. Moreover, LDH is released into the culture medium when cell trauma occurred [7]. In the current study, ligustrazine significantly increased SOD and GSH-Px activities but decreased $L D H$ release and MDA content. Thus, after pre-treatment with ligustrazine, HUVECs have the ability to resist damage from oxygen free radicals, reduce lipid peroxidation, and maintain biomembrane integrity. Moreover, according to the flow cytometry analysis of apoptosis, ligustrazine ameliorates apoptosis induced by oxidative stress. This observation is consistent with a previous study, which showed that ligustrazine can ameliorate apoptosis [14]. The current study demonstrates that ligustrazine is effective in protecting cells against oxidative damage induced by $\mathrm{H}_{2} \mathrm{O}_{2}$, which is particularly important in preventing the formation of atherosclerotic plaques.

NOS, the most important active enzyme in maintaining the physiological function of endothelial cells, has the ability to remove free radicals in vivo. Moreover, NOS is an enzyme responsible for the formation of NO [15], which is responsible for vasodilation, blood pressure regulation, cardiac contractility, and the mediation of immunity during bacterial infections and inflammation [16]. Compared with those of the control group, the $\mathrm{NO}$ and NOS expression levels of the $\mathrm{H}_{2} \mathrm{O}_{2}$ group decreased. However, the NO and NOS expression levels increased after pre-treatment with ligustrazine. The results suggest that the effect of ligustrazine on a meliorating $\mathrm{H}_{2} \mathrm{O}_{2}$-induced apoptosis is partly through the regulation of the NO pathway.

Massive vascular endothelial cell apoptosis occurs in atherosclerotic plaque. Moreover, excessive HUVEC apoptosis is involved in the initial stage of AS [17]. Hence, the prevention and control of AS by inhibiting the excessive apoptosis of vascular endothelial cells is greatly important.

Apoptosis may be mediated by two main signal transduction pathways, the death receptor pathway and mitochondrial induction pathways [18]. The triggering mechanism of the caspase cascade in apoptosis was explored in the current 
study to further confirm the protection against $\mathrm{H}_{2} \mathrm{O}_{2}$-induced apoptosis by ligustrazine. Recent evidence suggests that the opening of the mitochondrial permeability transition (MPT) pore is a critical event in the process, which leads to apoptosis under oxidative stress. The opening of the MPT pore can cause the dissipation of the inner mitochondrial transmembrane potential $\left(\Delta \Psi_{\mathrm{m}}\right)$, culminating in the disruption of outer membrane integrity, which then leads to the release of intermembrane proteins from the mitochondrion [19]. Once the pro-apoptotic factors move from the mitochondria into the cytosol, these apoptogenic proteins activate caspase proteases, amplifying apoptosis. Caspases are family members of cysteine proteases that mediate cell death and are critical regulators of apoptosis[20]. Studies have indicated that at least 11 kinds of caspase exist. Caspases 8 and 9 participate in the beginning of apoptosis, whereas caspase 3 is involved in the implementation of apoptosis. Our results show that the addition of ligustrazine attenuated the decrease in $\Delta \Psi_{m}$ and the up-regulation of caspase 3, 8, and 9 mRNA and activity, suggesting that the anti-apoptotic mechanism of ligustrazine against oxidative stress is a caspase-dependent pathway involved in mitochondrial induction pathways.

\section{CONCLUSION}

In summary, ligustrazine can protect HUVECs against $\mathrm{H}_{2} \mathrm{O}_{2}$-induced injury by regulating the indicators related to oxidative stress, enhancing anti-oxidant enzyme activity, and suppressing the overexpression of caspases 3,8 , and 9 . The protective mechanism of ligustrazine on $\mathrm{H}_{2} \mathrm{O}_{2}$ induced injury in HUVECs may be a caspasedependent, anti-apoptotic mechanism involved in mitochondrial induction pathways. The results of the present study provide important information for the treatment and prevention of oxidative stress-induced AS.

\section{ACKNOWLEDGEMENT}

We are grateful to the Self-determined Research Program of Jiangnan University (Project No.JUSRP11221) for financial support.

\section{CONFLICT OF INTEREST}

The authors declare that there are no conflicts of interest.

\section{REFERENCES}

1. Zou Z, Xu X, Huang $Y$, Xiao $X$, Ma L, Sun $T$, Dong $P$, Wang $X$, Lin $X$. High serum level of lutein may be protective against early atherosclerosis: The Beijing atherosclerosis study. Atherosclerosis 2011; 219: 789-793.

2. Wang B, Peng L, Zhu L, Ren P. Protective effect of total flavonoids from Spirodela polyrrhiza (L.) Schleid on human umbilical vein endothelial cell damage induced by hydrogen peroxide. Colloids and Surfaces B: Biointerfaces 2007; 60: 36-40.

3. Liu HT, He JL, Li WM, Yang Z, Wang YX, Bai XF, Yu C, Du YG. Chitosan oligosaccharides protect human umbilical vein endothelial cells from hydrogen peroxide-induced apoptosis. Carbohyd Polym 2010; 80: 1062-1071.

4. Liu HT, Li WM, Xu G, Li XY, Bai XF, Wei P, Yu C, Du YG. Chitosan oligosaccharides attenuate hydrogen peroxide-induced stress injury in human umbilical vein endothelial cells. Pharmacol Res 2009; 59: 167175.

5. Gille JJ, Joenje H. Cell culture models for oxidative stress: superoxide and hydrogen peroxide versus normobaric hyperoxia. Mutat Res 1992; 275: 405414.

6. Kaindl U, Eyberg I, Rohr-Udilova N, Heinzle C, Marian B. The dietary antioxidants resveratrol and quercetin protect cells from exogenous pro-oxidative damage. Food Chem Toxicol 2008; 46: 1320-1326.

7. Fu H, Li J, Li QX, Xia L, Shao L. Protective effect of ligustrazine on accelerated anti-glomerular basement membrane antibody nephritis in rats is based on its antioxidant properties. Eur J Pharmacol 2007; 563: 197-202.

8. Feng L, Xiong Y, Cheng F, Zhang L, Li S, Li Y. Effect of ligustrazine on ischemia-reperfusion injury in murine kidney. Transplant Proc 2004; 36: 1949-1951.

9. Cheng $X C$, Liu $X Y, X u, W F$, Guo $X L$, Zhang $N$, Song $Y N$. Ligustrazine derivatives. Part 3: Design, synthesis and evaluation of novel acylpiperazinyl derivatives as potential cerebrocardiac vascular agents. Bioorg Med Chem 2009; 17: 3018-3024.

10. M'Bemba-Meka P, Lemieux N, Chakrabarti SK.Role of oxidative stress, mitochondrial membrane potential, and calcium homeostasis in nickel subsulfideinduced human lymphocyte death in vitro. Sci Total Environ. 2006; 369: 21-34.

11. Oyagbemi AA, Adedara IA, Saba AB, Farombi EO.Role of oxidative stress in reproductive toxicity induced by co-administration of chloramphenicol and multivitamin-haematinics complex in rats. Basic Clin Pharmacol Toxicol 2010; 107: 703-708.

12. Csiszar A, Smith KE, Koller A, Kaley G, Edwards, JG, Ungvari Z.Regulation of bone morphogenetic protein2 expression in endothelial cells: role of nuclear factor-kappaB activation by tumor necrosis factoralpha, $\mathrm{H}_{2} \mathrm{O}_{2}$, and high intravascular pressure. Circulation 2005; 111: 2364-2372.

13. Liu YM. Jiang B, Bao YM, An LJ. Protocatechuic acid inhibits apoptosis by mitochondrial dysfunction in rotenone-induced PC12 cells. Toxicol In Vitro 2008; 22: 430-437.

14. Feng $L$, Ke N, Chen F, Gu Y, Li S, Li Q, Li, Y. The protective mechanism of ligustrazine against renal ischemia/reperfusion injury. J Surg Res 2011; 166: 298-305.

15. Ueta Y, Levy A, Chowdrey HS, Lightman SL. Water deprivation in the rat induces nitric oxide synthase (NOS) gene expression in the hypothalamic paraventricular and supraoptic nuclei. Neurosci Res 1995; 23: 317-319.

16. Felaco $M$, Di Maio FD, De Fazio $P$, D'Arcangelo $C$, De Lutiis MA, Varvara G, Grilli A, Barbacane RC, Reale $M$, Conti $P$. Localization of the e-NOS enzyme in endothelial cells and odontoblasts of healthy human dental pulp. Life Sci 2000; 68: 297-306.

17. Park S, Kim JA, Choi S, Suh SH. Superoxide is a potential culprit of caspase-3 dependent endothelial 
cell death induced by lysophosphatidylcholine. $J$ Physiol Pharmacol 2010; 61: 375-381.

18. Bustamante J, Caldas Lopes E, Garcia M, Di Libero E Alvarez E, Hajos SE. Disruption of mitochondrial membrane potential during apoptosis induced by PSC 833 and CsA in multidrug-resistant lymphoid leukemia. Toxicol Appl Pharmacol 2004; 199: 44-51.

19. Ouyang YB, Carriedo SG, Giffard RG. Effect of $B c l-X_{L}$ overexpression on reactive oxygen species, intracellular calcium, and mitochondrial membrane potential following injury in astrocytes. Free Radical Bio Med 2002; 33: 544-551.

20. Lago J, Santaclara F, Vieites JM, Cabado AG. Collapse of mitochondrial membrane potential and caspases activation are early events in okadaic acid-treated Caco-2 cells. Toxicon 2005; 46: 579-586. 